\title{
Larerikt å forske selv om jeg"bare" er student! Studentaktiv forskning på barnehagelærerutdanningen
}

\author{
Hilde Nancy Skaug og Heid Osnes \\ OsloMet-storbyuniversitetet
}

\begin{abstract}
I denne artikkelen presenteres et eksempel på forskningsbasert utdanning med studentaktiv forskning samt studenters evaluering av å delta i forskning som en integrert del av studiet. Det empiriske grunnlaget består av deskriptive data fra en spørreundersøkelse blant to kull deltidsstudenter ved førskolelærerutdanningen ved Høgskolen i Oslo og Akershus (HiOA) ${ }^{\mathrm{x}}$. De fleste studier av studentaktiv forskning er gjort på viderekomne studenter. Vår studie viser at førsteårs bachelorstudenter kan ha utbytte av å delta i forskning, men at mange studenter synes det er vanskelig å tilegne seg forskningslignende ferdigheter innenfor kvantitativ metode.
\end{abstract}

Nøkkelord: studentaktiv forskning, forskning-undervisning, førsteårs bachelorstudenter, kvantitativ forskning, studentevaluering, profesjonsrelevant

\section{INNLEDNING}

Universitets- og høyskoleloven i Norge (2005) slår fast at all høyere utdanning skal baseres på "... det fremste innen forskning, faglig og kunstnerisk utviklingsarbeid og erfaringskunnskap" (\$I-3, pkt. a). Dette omtales ofte som forskningsbasert utdanning og gjennomføres ved at forskning og undervisning knyttes tettere sammen (Kunnskapsdepartementet, 2013). Det er ingen enhetlig forståelse for hvordan forskningsbasert utdanning skal praktiseres eller hvordan forskning og undervisning skal knyttes sammen. Forskningsbasert utdanning kan gjennomføres ved at undervisningen er i overensstemmelse med nyere forskningsresultater, at undervisningen er knyttet til et forskningsmiljø, at lærere har forskningskompetanse og/eller at lærere selv er aktive forskere (Universitets- og høgskolerådet, 20IO). Barnehagelærerutdanningen skal bygge på vitenskapelig kunnskap, men som i andre profesjonsutdanninger skal studentene også tilegne seg kompetanse og ferdigheter i et spesifikt yrke. Dette betyr at utdanningen bør være både forskningsbasert og praktisk. Det blir da viktig for studentene at den vitenskapelige kunnskapen har relevans for deres profesjonsutøvelse (Universitets- og høgskolerådet, 20Io), og at utdanningsinstitusjonene legger til rette for et forpliktende samspill med praksisfeltet (Kunnskapsdepartementet, $2012 \$ I$ ).

God kvalitet i utdanningen sikrer at studenter tilegner seg kompetanse og kunnskap som dekker arbeidslivets behov (Kunnskapsdepartementet, 20I7b). Kvalitet er et komplekst og flerdimensjonalt begrep, men handler om hvordan læringsaktiviteter og arbeidsformer støtter opp

1 Høsten 2011 ble høgskolene i Oslo og Akershus slått sammen til HiOA. Høsten 2013 ble førskolelærerutdanningen endret til barnehagelærerutdanning. I 2018 fikk HiOA universitetsstatus og fikk navnet OsloMet - storbyuniversitetet.

*Författarkontakt: hildena@oslomet.no 
om studentenes læring (Damsa et al., 20I5). Utdanningen skal også bidra til studentenes dannelse (Kulturdepartementet, 20I7b). Dannelsesbegrepet er sammensatt og omstridt, og det er først de seneste årene trukket inn i generelle debatter om høyere utdanning (Hjardemaal \& Jordell, 20II). Enkeltinstitusjoner i universitets- og høyskolesektoren nedsatte i 2007 et frittstående utvalg - Dannelsesutvalget - som skulle se nærmere på hvordan den akademiske dannelsen blir ivaretatt i høyere utdanning i Norge. Dannelsesutvalget (2009) reserverer seg mot en generell definisjon av begrepet, men problematiserer hva dannelse kan være i høyere utdanning. Utvalget diskuterer ulike forståelser av begrepet, men mener generelt at tema og spørsmål knyttet til "kritisk refleksjon, innsikt i vitenskapelig tenkemåte og erkjennelseslære, faglig fordypning, saklighetslære og etisk kompetanse" (Dannelsesutvalget, 2009, s. 3), kan relateres til ulike aspekter ved studentenes dannelsesprosess.

Tradisjonelle undervisningsformer kritiseres ofte for å begrense studentenes læring og oppmerksomhet, og mange hevder at for eksempel forelesninger kan virke passiviserende (Damsa et al., 20I5). I Kvalitetsreformen (Kunnskapsdepartementet, 200I) pekes det på at utdanningsinstitusjonene i større grad bør ta i bruk studentsentrerte læringsaktiviteter, der studenter involveres i faglige spørsmål knyttet til faget det undervises i eller til profesjonsfeltet. Dette betegnes ofte som studentaktiv forskning. Den siste forskningsmeldingen oppfordrer utdanningsinstitusjonene til å legge til rette for studentaktiv forskning allerede på bachelornivå, og å anvende studenter som en ressurs for forskning (Kunnskapsdepartementet, 20I3). Fremtredende argumenter for at studenter bør få praktisk erfaring med forsknings- og utviklingsarbeid, er at de får dypere innsikt i faget, blir mer selvstendige og utvikler større evne til analytisk problemløsning og kritisk tenkning (Kunnskapsdepartementet, 20I6; Kunnskapsdepartementet, 20I7b). Dette er også en del av studentenes dannelsesprosess. Gjennom dybdelaring kan studenter gradvis utvikle økt forståelse for metoder, begreper og sammenhenger mellom kunnskapsområder (NOU 20I4:7, kap. 3). Dybdelæring er ikke bare knyttet til kognitive ferdigheter, men er også tett forbundet med holdninger til og antagelser om hvordan man kan forholde seg til kunnskap. I denne forståelsen blir dybdelæring en forutsetning for studentenes dannelsesprosess som medmenneske og reflekterende samfunnsborger.

Flere studier viser at studentaktiv forskning brukes i begrenset grad i høyere utdanning i Norge (Kyvik \& Vågan, 20I4; Kulturdepartementet, 20I7b). Resultater fra studier av studentaktiv forskning innen høyere utdanning peker i ulike retninger. På den ene siden viser studier at studenter ofte opplever et gap mellom forskningsprosjekt de deltar i, pensum og øvrig undervisning (Kyvik \& Vågan, 20I4; Vågan \& Havnes, 20I3). Årsaken kan være at studentene har en annen oppfatning enn de vitenskapelig ansatte av hva forskning betyr i praksis eller at temaet det forskes på faller utenfor studieprogrammets kjerneområder. På den annen side viser forskning at studenter mener de lærer mest når de deltar aktivt i forskningslignende aktiviteter (Justice et al., 2007; Kyvik \& Vågan, 20I4; Jenkins, Breen \& Lindsay, 2003; Healey, 2005). De er mer fornøyde, opplever større grad av trivsel og utvikler større evne til kritisk og selvstendig tenkning (Justice et al., 2007; Pascarella \& Terenzini, 2005; Nnadozie, Ishiyama \& Chon, 200I). Gjennom å delta i forskningslignende aktiviteter synes studenter i større grad å tilegne seg ferdigheter og holdninger som er viktige i deres dannelsesprosess og for deres fremtidige yrkesutøvelse (Nnadozie et al., 200I).

Vi kjenner ikke til eksempler hvor lærere har involvert hele studentkull på lavere grads nivå i sin forskning. Enkelte lærere inviterer de dyktigste studentene som medforskere i forbindelse med bacheloroppgaven, men dette skjer oftest på master- og doktorgradsnivå (Kulturdepartementet, 20I7b). Til sist ser vi en tendens til at tidligere studier på studentaktiv forskning i 
profesjonsutdanningene i liten grad har undersøkt hvordan studenter kan tilegne seg forskningsferdigheter innen kvantitativ metode (Kyvik \& Vågan, 20I4). I barnehagelærerutdanningen er det ofte fokus på kvalitative metoder, fordi mange anser at kjernespørsmålene i barnehagesektoren best lar seg belyse med kvalitative forskningsdesign.

For å heve kvaliteten i høyere utdanning bør utdanningsinstitusjonene forske på egen undervisning (Kulturdepartementet 20I7b; Damşa et al., 20I5; Pascarella \& Terenzini, 2005). OECD (20I2) understreker betydningen av at også studenter på lavere grads nivå blir lyttet til: "Pay attention to varied student viewpoints according to their status and seniority (e.g., freshmen react differently from doctoral students, but their views are worth considering)" (OECD, 20I2, s. 22). Fordi det primært er viderekomne studenter som involveres i forskning, er de fleste evalueringer av studentaktiv forskning foretatt på studentgrupper med flere års studieansiennitet.

Tidligere studier viser at studenter motiveres til vitenskapelig tenkning når de deltar i forskning (Spronken-Smith \& Walker, 20I0; Boyer Commission, 1998). I vårt forskningsprosjekt for studentaktiv forskning deltok to lærere og 280 førsteårs deltidsstudenter på førskolelærerutdanningen ved HiOA, fra og med høsten 2010 til sommeren 2013. Vi mener det er spesielt viktig at førsteårsstudenter får forskningserfaring, slik at de tidlig i studieløpet lærer å reflektere over fagstoffet de møter og ser dette i sammenheng med observasjoner fra praksis. Studentene fikk undervisning i fysisk fostring første studieår, parallelt med naturfag og pedagogikk. Studentene arbeidet deltid i skole eller barnehage ved siden av å være studenter $50 \%$ av tiden. Studenter som begynte på deltidsutdanningen i denne perioden, hadde minst ett års relevant forpraksis²

Hensikten med vår studie er å fremskaffe ny kunnskap om studentaktiv forskning med førsteårs bachelorstudenter, som kan bidra til å heve kvaliteten i utdanningen (Kulturdepartementet, 2017b).

Spørsmålene vi belyser $i$ denne artikkelen er:

I. I hvilken grad opplevde studentene sammenheng mellom undervisning og forskning?

2. Hvilket læringsutbytte, innen kvantitativ forskningsmetode, rapporterte studentene at de fikk gjennom å delta i et lærerstyrt forskningsarbeid?

3. I hvilken grad opplevde studentene at forskningsarbeidet hadde relevans for arbeidet $\mathrm{i}$ barnehagen?

Vi bruker "undervisning" om all tilrettelegging for læring, herunder forelesninger, veiledning og praktisk undervisning.

FORSKNINGSBASERT UTDANNING - ET ANALYTISK PERSPEKTIV

Forskningsbasert utdanning har linjer tilbake til Tyskland på I80o-tallet og den Humboldtske tradisjon, som innebar at det skulle være enhet mellom undervisning og forskning (Jenkins \& Healey, 20IO). Amerikaneren Ernest Boyer videreutviklet prinsippene for hvordan undervisning og forskning kunne knyttes tettere sammen i høyere utdanning (Boyer Commission, 1998). Hans arbeid fikk stor internasjonal oppmerksomhet, blant annet fordi han anbefalte at studenter bør delta i forskning allerede første studieår. Det er utviklet flere modeller for hvordan forskning og undervisning kan knyttes sammen i høyere utdanning. Vi har valgt å benytte Healeys modell (Healey, 2005), som er tydelig inspirert av Boyers ideer.

2 Krav om forpraksis i 2012: https://www.samordnaopptak.no/info/pdfer/Sokerhandboka2012.pdf Krav om forpraksis i 2011: https://www.samordnaopptak.no/info/pdfer/Sokerhandbok-2011.pdf 


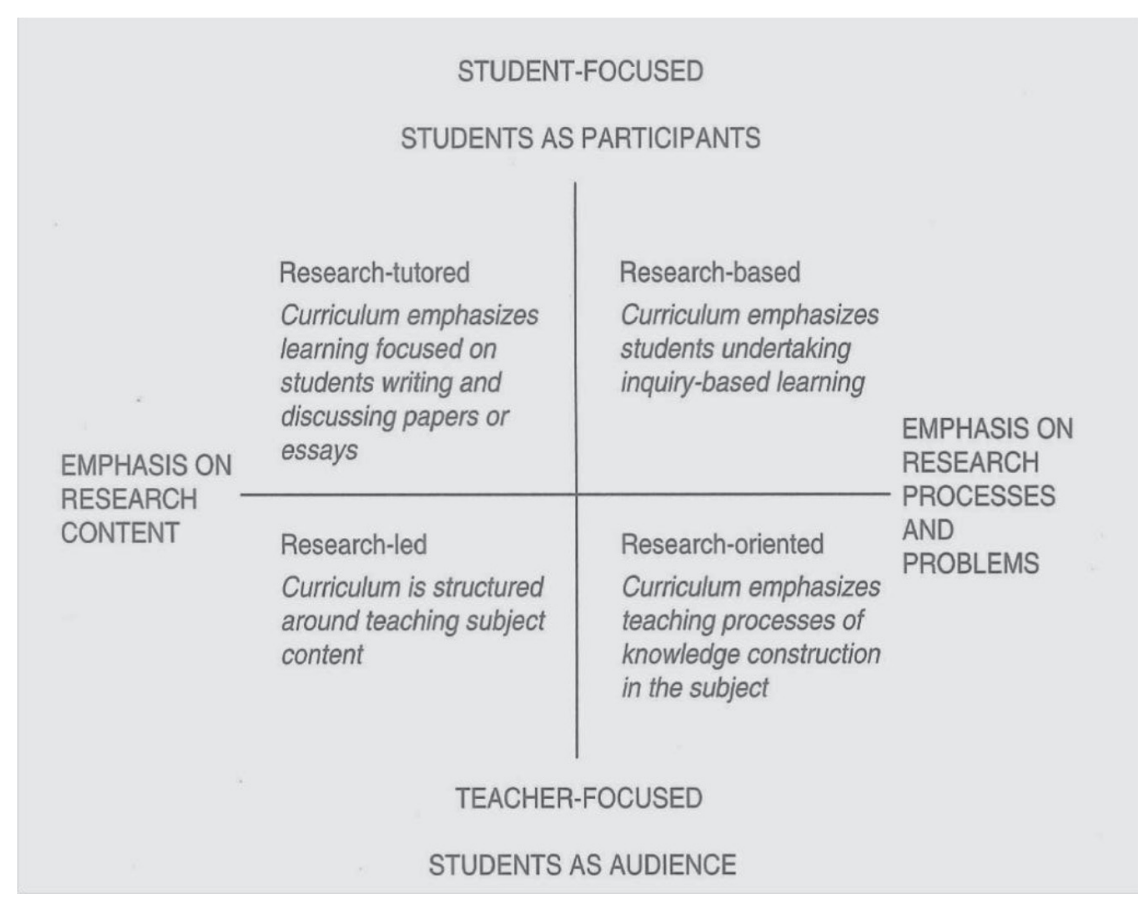

Figur I. En modell for forskningsbasert utdanning (Healey, 2005, figur 5.2)

Modellen for forskningsbasert utdanning (figur I) består av fire læringsaktiviteter. Venstre side av den loddrette aksen illustrerer undervisning i faglige temaer og forskning knyttet til disse, mens den høyre siden refererer til forskningsaktiviteter og metodelære. Lærersentrerte læringsaktiviteter er plassert under den vannrette aksen, mens studentsentrerte læringsaktiviteter er plassert over. I lærersentrerte læringsaktiviteter formidles nyere forskningsresultater innen faget (research-led) og/eller det undervises i tema knyttet til forskningsprosesser og vitenskapelige metoder (research-oriented). I studentsentrerte læringsaktiviteter er studentene aktive i faglige diskusjoner (research-tutored) og/eller studentene utfører egen forskning (research-based).

Studentaktive læringsformer synes å bidra til dybdelæring som gir større kapasitet for mer avansert kunnskapsarbeid (Damsa et al., 20I5). Den tyske pedagogen Klafki mener didaktikk bør baseres på dannelsesteorier (Klafki, 20I4). Historisk sett har det vært vanlig å dele dannelsesbegrepet i material og formal dannelse (Foros \& Vetlesen, 20I2). Material dannelse vektlegger det objektive, her representert ved temaer og teorier studentene undervises i. Dette kan ha likhetstrekk med begrepene research-led og research-oriented, der læreren er kunnskapsformidler (Healey, 2005). Formal dannelse vektlegger det subjektive, som at studentene tilegner seg holdninger, arbeidsvaner og tenkemåter gjennom selv å være aktive og ta del i egen læringsprosess. Dette kan foregå gjennom læringsaktivitetene resarch-tutored og research-based (Healey, 2005). Klafki hevder det er et avhengighetsforhold mellom det formale og materiale og kaller en kombinasjon av disse for kategorial dannelse (Klafki, 20I4). I dette perspektivet vil Healeys modell (2005) for forskningsbasert utdanning være et eksempel på at en kombinasjon av studentsentrerte og lærersentrerte læringsaktiviteter kan bidra til studentenes kategoriale dannelse. 
Prinsippet om eksemplarisk laring er også sentralt i Klafkis dannelsesteorier (20I4). Dette henspiller til at en i undervisningen bør trekke frem eksempler som er typiske eller som er vesentlige i faget, og som kan hjelpe den enkelte studenten til å bli mer kritisk og selvstendig i søken etter ny kunnskap. Klafki (20I4) legger til grunn to kriterier for eksemplarisk læring: det fundamentale og det elementare prinsippet. Det fundamentale henviser til studenten og dens grunnleggende erfaringer og kunnskap. Det elementære viser til det faglige innholdet $\mathrm{i}$ undervisningen og innholdets relevans for det yrket studenten utdannes til. Kategorial dannelse er avhengig av et samspill mellom det elementære og det fundamentale prinsippet (Klafki, 20I4).

\section{BESKRIVELSE AV VÅRT PROSJEKT MED FORSKNINGSBASERT UNDERVISNING}

Begrepet utdanning benyttes ofte som samlebetegnelse for hele utdanningsretninger, studietilbud eller undervisning innen disse (Universitets- og høgskolerådet, 2010). Vi bruker betegnelsen forskningsbasert undervisning når vi omtaler møtet mellom fagstoffet, lærere og studenter i vårt opplegg.

Vårt opplegg for forskningsbasert undervisning er inspirert av Healeys modell (2005) skissert i figur I. Studentene deltok i forskning sammen med to lærere (research-based), der problemstillingen var å avdekke faktorer som hemmer og fremmer kroppslig lek i barnehagen (Osnes \& Skaug, 20I5 a og b). Kroppslig lek defineres som "fysisk aktivitet i lekende kontekst med energiforbruk godt over hvilenivå” (Osnes, Skaug \& Kaarby, 20I7, s. I45). Det typiske ved denne formen for lek er at barna blir andpustne, svette og ofte litt slitne. Problemstillingen, som ble utformet av lærerne, er forankret i rammeplanen for barnehagens innhold og oppgaver i kunnskapsområdet Kropp, bevegelse, mat og helse (Kunnskapsdepartementet, 2017a).

Tabell I. Laringsaktiviteter i kronologisk rekkefolge, i relasjon til Healeys modell for forskningsbasert utdanning (2005)

\begin{tabular}{|c|c|c|}
\hline Måned & Læringsaktiviteter & $\begin{array}{l}\text { I relasjon til Healeys modell } \\
(2005) \text {. Se figur I }\end{array}$ \\
\hline pkt. I: august - april & $\begin{array}{l}\text { Forelesninger om faglige tema i fysisk fostring og } \\
\text { praktisk undervisning }\end{array}$ & - \\
\hline pkt. 2: september & Studentene introduseres for forskningsprosjektet & - \\
\hline pkt. 3: september - november & $\begin{array}{l}\text { Forelesninger med fokus på resultater av } \\
\text { forskning på barns kroppslige lek }\end{array}$ & Research-led \\
\hline pkt. 4: september - november & $\begin{array}{l}\text { Forelesninger om observasjon som metode og } \\
\text { forskningsetikk. }\end{array}$ & Research-oriented \\
\hline pkt. 5: september - november & $\begin{array}{l}\text { Introduksjon, utprøving, revidering og endelig } \\
\text { utforming av observasjonsskjema }\end{array}$ & Research-oriented / Research-based \\
\hline pkt. 6: november - februar & Observasjon av barns kroppslige lek i barnehagen & Research-based \\
\hline pkt. 7: november & Opplæring og registrering i regneark (Excel) & Research-oriented \\
\hline pkt. 8: februar & Analyse av data, som ble publisert på Fronter & Research-based \\
\hline pkt. 9: september - april & Individuell veiledning og klasseveiledning & Research-tutored \\
\hline pkt. IO: mai & Innlevering av skriftlig hjemmeeksamen & Research-based \\
\hline
\end{tabular}


Tabell I viser læringsaktivitetene som ble benyttet i undervisningen i fysisk fostring første studieår, i relasjon til Healeys modell (2005) for forskningsbasert utdanning. Selv om Healey (2005) ikke nevner eksplisitt at studenter bør få en faglig innføring i temaet det forskes i, valgte vi å gi studentene forelesninger og praktisk undervisning i fysisk fostring de første ukene av studieåret (tabell I, pkt. I). Dette mente vi var hensiktsmessig for at studentene skulle bli kjent med terminologien i faget, og dermed lettere forstå problemstillingen i en faglig kontekst. Forskningsprosjektet ble presentert tidlig i semesteret (tabell I, pkt. 2), før resultater fra andre relevante undersøkelser ble gjort kjent for studentene (tabell I, pkt. 3). Lærerne valgte observasjon som metode for innhenting av data. I forelesninger om forskningsmetode ble det lagt vekt på ulike sider ved observasjon som metode for innhenting av kvantitative data (tabell I, pkt. 4). Studentene fikk presentert et utkast til et strukturert observasjonsskjema med lukkede og åpne svarkategorier, som de prøvde ut på barnegrupper i gymsal to ganger. Utformingen av observasjonsskjemaet ble videre diskutert med studentene, utbedret og resulterte i et endelig skjema som studentene senere benyttet ved innhenting av data i barnehagene de arbeidet i (tabell I, pkt. 5). Studentene observerte barnas lek i ulike fysiske miljø (tabell I, pkt. 6). Studentene fikk opplæring i bruk av regneark og hvordan de skulle legge observasjonsdataene inn i en Excel-fil på læringsplattformen Fronter (tabell I, pkt. 7). Dataene ble lagt inn i regnearket, analysert og lagt ut på Fronter i form av tabeller og diagram (tabell I, pkt. 8). Studentene fikk veiledning gjennom hele studieåret (tabell I, pkt. 9). Studentene benyttet observasjonsdataene i sin skriftlige hjemmeeksamen (tabell I, pkt. Io). Hver student utformet en underproblemstilling knyttet til spørsmålet om hvilke faktorer som fremmer og hemmer barns kroppslige lek i barnehagen. Denne ble drøftet i forhold til utvalgte observasjonsdata, relevant teori og resultater fra sammenlignbare studier.

Healey (2005) anbefaler at studenter bør tilegne seg forskningsbasert kunnskap første studieår (f.eks. research-led) som grunnlag for mer avanserte former mot slutten av studiet (f.eks. research-based). Vi valgte imidlertid å benytte alle de fire læringsaktivitetene første studieår, blant annet fordi dette kunne bidra til studentenes kategoriale dannelse (Klafki, 20I4).

\section{METODISK TILNÆRMING}

Tre studentkull deltok i vårt opplegg for forskningsbasert undervisning. For å bli kjent med studentenes evaluering av undervisningen utarbeidet vi to skjema. 70 studenter i det første kullet (20IO-20II) svarte på et papirbasert spørreskjema. Disse tilbakemeldingene er å betrakte som en pilotstudie og ligger til grunn for utarbeidelse av det endelige spørreskjemaet. Vi fikk for eksempel tilbakemeldinger på at enkelte spørsmål var utydelig formulert og dermed måtte omformuleres. Resultatene fra pilotstudien er ikke en del av resultatene som diskuteres i denne artikkelen.

Vi benyttet en databasebasert applikasjon på nett, SiFra, ved HiOA til å utvikle et digitalt spørreskjema, som ble distribuert til 2IO studenter i de to påfølgende studentkullene (2OII-2OI2 og 20I2-2013). Spørreskjemaet ble lagt ut på Fronter i juni etter at undervisningen i fysisk fostring var avsluttet, og etter at studentene hadde fått sine eksamenskarakterer. Spørreskjemaet ble etter to purringer besvart av 80 studenter (38\%). Disse tilbakemeldingene ligger til grunn for resultatene som diskuteres i denne artikkelen. Vi vet ikke hvorfor ikke flere studenter svarte på spørreskjemaet. Den mest sannsynlige forklaringen er at mange studenter ikke fikk informasjon om spørreundersøkelsen, fordi de ikke logget seg på Fronter etter avsluttet semester. Det kan også være at enkelte studenter ikke ønsket å svare på spørsmålene. 
Spørsmålene ble utformet på grunnlag av pilotstudien, andre sammenlignbare studier, offentlige dokumenter og utredninger om forskningsbasert utdanning. Spørreskjemaet bestod av 19 spørsmål. I denne artikkelen belyser vi kun tre av dem. I disse spørsmålene ble studentene bedt om å ta stilling til i hvilken grad de var enige eller uenige i påstander om sammenheng mellom undervisningen og forskningsarbeidet, og i hvilken grad de mente forskningsarbeidet var relevant for deres arbeid i barnehagen. I vurderingen av læringsutbytte fikk studentene presentert Is påstander, og krysset av ved fem påstander de kjente seg mest igjen i.

Vi benyttet IBM SPSS Statistics i analysene av datamaterialet. Enkeltvariablene i datamaterialet er analysert ved hjelp av frekvenstabeller og deskriptiv statistikk for å vise hvordan enhetene fordeler seg på variablene i datamaterialet. Frekvensfordelingen oppgis både i antall og prosent. Det er foretatt kun univariate frekvensfordelinger, fordi bivariate analyser ikke var tilgjengelig. I presentasjonen av resultatene er svaralternativene "svært enig" og "enig" slått sammen på samme måte som "svært uenig" og "uenig". Dette har vi valgt for å gi et tydeligere bilde av i hvilken grad studentene kjente seg igjen i påstandene de fikk presentert.

\section{Etiske overveielser}

Alle studentene ble invitert til å delta i evalueringen. Forskningsetiske retningslinjer om frivillighet og anonymitet ble overholdt. Studentene ble informert om at resultater fra studentevalueringene kunne bli presentert på konferanser og publisert i vitenskapelige tidsskrift.

\section{Metodekritikk}

Fordi vi har begrenset kjennskap til karakteristika ved utvalget og hele studentgruppen, er det vanskelig å vite i hvilken grad utvalget er representativt for populasjonen. Eksamensprotokoller ved $\mathrm{HiOA}$ viser at $\mathrm{C}$ var gjennomsnittskarakteren på eksamen i fysisk fostring de aktuelle årene, og at karakterene var tilnærmet normalfordelt, både i utvalget og i populasjonen. Det er derfor liten grunn til å tro at frafallet kan kobles til studentenes faglige dyktighet. I utvalget var $8 \mathrm{r} \%$ kvinner og $19 \%$ menn, mens populasjonen besto av $76 \%$ kvinner og $24 \%$ menn $^{3}$. Det betyr at frafallet neppe var knyttet til studentenes kjønn. Vi vet lite om det var forskjeller i utvalget og populasjonen når det gjelder andre forhold, som for eksempel alder og antall år med arbeidserfaring. Vi vet dog at både utvalget og populasjonen besto av studenter med minst ett års relevant forpraksis.

Det kan være en utfordring at studentenes evalueringer baserer seg kun på selvrapportering, der studentene vurderte egen kompetanse. På spørsmålet om læringsutbytte skulle studentene krysse av for påstander de kjente seg mest igjen i. Vi vet ikke om andre påstander kunne ha beskrevet studentens læringsutbytte bedre, eller i hvor stor grad de kjente seg igjen i påstandene.

\section{RESULTATER}

Studentenes svar, som belyser artikkelens tre forskningsspørsmål, presenteres hver for seg.

\section{Sammenheng mellom undervisning og forskning}

Forskningsbasert utdanning kan gjennomføres ved at undervisning og forskning knyttes tettere sammen, for eksempel gjennom studentaktiv forskning, som Healey (2005) betegner som research-based. Tidligere studier gir ikke entydige svar på i hvilken grad studenter opplever at det er sammenheng mellom undervisning og forskning de deltar i (Justice et al., 2007; Zamorski, 2010).

3 Informasjonen er hentet fra eksamensprotokoller ved HiOA. 
Tabell 2. Påstand: Jeg har sett stor sammenheng mellom forelesninger, veiledninger og forskningsarbeidet

\begin{tabular}{|l|c|c|}
\hline & Frekvens & I prosent \\
\hline Svært enig eller enig & 77 & 96 \\
\hline Uenig & 2 & 3 \\
\hline Vet ikke & I & I \\
\hline Sum & 80 & I00 \\
\hline
\end{tabular}

Tabell 2 viser at nesten alle studentene (96\%) var svært enig eller enig $i$ at det var stor sammenheng mellom forelesningene (research-led og research-oriented), veiledningene (research-tutored) og forskningen de deltok i (research-based). Kun tre prosent var uenig i påstanden om at det var stor grad av sammenheng mellom læringsaktivitetene.

\section{Laringsutbytte av å delta i forskning}

Flere studier viser at studenter opplever størst læringsutbytte når de selv deltar i forskning (Justice et al., 2007; Jenkins et al., 2003). For å få tilbakemeldinger på hva studentene hadde lært om kvantitativ forskning, ba vi dem ta stilling til Is påstander og krysse av for fem påstander de kjente seg mest igjen i.

Tabell 3. Studentenes laringsutbytte av à delta i forskning, $N=80$

\begin{tabular}{|c|c|c|c|}
\hline Påstand nr. & Læringsutbytte & Frekvens & I prosent \\
\hline I & Lært om observasjon som metode & 82 & 83 \\
\hline 2 & $\begin{array}{l}\text { Lært om feilkilder og hvilken betydning det kan ha for resultatene i en } \\
\text { undersøkelse }\end{array}$ & 57 & 58 \\
\hline 3 & Fått forståelse for at observasjon som metode aldri er helt objektiv & 54 & 55 \\
\hline 4 & $\begin{array}{l}\text { Lært at resultater fra observasjoner ikke alltid stemmer med egne } \\
\text { forventninger }\end{array}$ & $5 \mathrm{I}$ & 52 \\
\hline 5 & Erfart at tolkning av data er vanskelig & 49 & 49 \\
\hline 6 & $\begin{array}{l}\text { Lært mye om hva man må tenke på når man bruker observasjon som } \\
\text { metode for innsamling av data }\end{array}$ & 47 & 47 \\
\hline 7 & Lært å være kritisk til egne undersøkelser og til data og forskning jeg leser & 44 & 44 \\
\hline 8 & Lært at det å observere er intenst og krever full konsentrasjon & 38 & 38 \\
\hline 9 & Fått innblikk i forskningsarbeid: innsamling av data, registrering og analyse & 36 & 36 \\
\hline IO & Lært å lage egne tabeller og diagram & 30 & 30 \\
\hline II & Lært hvor viktig det er å legge følelsene til side når man observerer barn & 29 & 29 \\
\hline $\mathrm{I} 2$ & Lært om hvordan man behandler data fra observasjon & 24 & 24 \\
\hline $\mathrm{I} 3$ & Lært å bruke Excel & 19 & 19 \\
\hline I4 & Forstår mer hva det betyr å forske & 17 & 17 \\
\hline 15 & Lært å lese tabeller & I5 & I5 \\
\hline
\end{tabular}

Vi finner stor spredning i studentenes svar om læringsutbytte (tabell 3 ). Flest studenter markerte at de hadde lært mest om observasjon som metode (påstand nr. I, 3, 4, 6 og 8) og at forskningsresultater kan være beheftet med feilkilder (58\%). $44 \%$ svarte at de hadde lært å være kritiske til egne og andres forskningsresultater. Nesten halvparten av studentene syntes det var vanskelig 
å tolke data. Færre studenter oppga at de hadde tilegnet seg ferdigheter innenfor kvantitativ forskning, som å lage tabeller og diagram (30\%), bruke Excel (19\%) og lese tabeller (15\%).

\section{Forskningsarbeidets relevans for arbeidet $i$ barnehagen}

En av anbefalingene for studentaktiv forskning i profesjonsutdanningene er at forskningen bør knyttes til praksisfeltet (Kunnskapsdepartementet, 20I2). Studentene ble bedt om å ta stilling til påstanden om at forskningsarbeidet hadde gitt dem erfaringer og kunnskap som var relevant for deres profesjonsutøvelse.

Tabell 4. Påstand: Jeg mener erfaringer og kunnskap knyttet til prosjektet kroppslig lek har relevans for mitt arbeid $i$ barnehagen

\begin{tabular}{|l|c|c|}
\hline & Frekvens & I prosent \\
\hline Svært enig eller enig & 75 & 94 \\
\hline Svært uenig eller uenig & 2 & 2 \\
\hline Vet ikke & 3 & 4 \\
\hline Totalt & 80 & 100 \\
\hline
\end{tabular}

Tabell 4 viser at $94 \%$ av studentene var svært enig eller enig i påstanden om at forskningsprosjektet hadde relevans for deres arbeid i barnehagen. Kun fire prosent var usikre, og to prosent var ikke enig i at prosjektet var relevant for deres fremtidige profesjonsutøvelse.

\section{DISKUSJON}

Vi diskuterer først studentenes oppfatninger av sammenheng mellom undervisningen og forskningsarbeidet, før vi belyser studentenes svar på hva de lærte av å delta i forskning. Til slutt diskuterer vi forskningsarbeidets relevans for deres fremtidige arbeid i barnehagen.

\section{Sammenheng mellom undervisning og forskning}

Nesten alle studentene svarte at det var stor sammenheng mellom forelesninger, veiledninger og forskningsarbeidet (tabell 2), ofte beskrevet som forskningsbasert utdanning (Kunnskapsdepartementet, 2013). Det kan være noe overraskende at så mange førsteårsstudenter opplevde denne sammenhengen, da andre studier viser at studenter ser denne sammenhengen først når de er kommet lenger i studiet (Zamorski, 20Io). Dette mener vi kan handle om hvordan forskningsarbeidet ble integrert med forelesninger og veiledninger, og at vi benyttet alle de fire læringsaktivitetene Healey (2005) skisserer for forskningsbasert utdanning. At alle læringsaktivitetene ble benyttet i samme studieår, kan ha bidratt til at studentene lettere kjente igjen tema fra forelesningene når de arbeidet med forskningsprosjektet. En annen tolkning kan være at studentene opplevde stor sammenheng mellom læringsaktivitetene fordi de benyttet observasjonsdataene i sine eksamensoppgaver. Hver av besvarelsene ble mindre forskningsrapporter, der studentene erfarte at både teori, metodekunnskap og data er nødvendig for å belyse en problemstilling.

Vi kjenner ikke til studentevalueringer der en har undersøkt betydningen av veiledning (research-tutored) i studentaktiv forskning. Erfaringer fra vårt opplegg er at regelmessige veiledninger ble et naturlig bindeledd mellom forelesningene og forskningsarbeidet (Boyer Commission, 1998). 
Laringsutbytte av à delta i forskning

Studentene deltok i utvikling av observasjonsskjemaet, observerte i barnehagene og benyttet resultatene i sin hjemmeeksamen, slik Healey (2005) definerer som research-based. Tidligere studier bekrefter at aktiv involvering i forskning kan være gunstig for studentenes læring (Brew, 2006; Pascarella \& Terenzini, 2005; Justice et al., 2007; Jenkins et al., 2003), og det var derfor ikke overraskende at $83 \%$ av studentene oppga at de hadde lært om observasjon som metode (tabell 3). Mange studenter (58\%) hadde erfart og forstått at forskning kan være forbundet med feilkilder, og nesten halvparten (44\%) hadde lært at en må lese forskningsrapporter med kritisk blikk. Sentralt i kritisk tenkning er å reflektere over kilders troverdighet, samt å akseptere at forskningsdata kan forstås på ulike måter. Dette er kunnskap og forståelse som kan bidra til at studenter blir kritiske og reflekterte samfunnsborgere, som er sentralt i Klafkis dannelsesteori (20I4).

Over halvparten av studentene ( $55 \%)$ hadde fått erfaring med at observasjon aldri vil være nøytral eller sann, da ulike situasjoner kan oppleves forskjellig både av barn og voksne. Litt over halvparten av studentene ( $51 \%)$ erfarte at resultatene ikke alltid sammenfalt med egne forventinger, og $29 \%$ av studentene mente det var viktig å legge egne følelser til side under observasjon. Dette er viktige erfaringer i profesjonsutøvelsen. Til sammen kan svarene tolkes som at flere studenter var blitt ydmyke til egne evner og ferdigheter knyttet til forskning, og at mange hadde forstått at forskning, særlig tolkning av data, er en krevende og kompleks prosess. Samtidig kan studentene ha opplevd at jo mer innsikt de fikk i forskningsprosessen, jo mer kunnskap og erfaring hadde de behov for. I et læringsperspektiv kan en slik erkjennelse være et eksempel på, og en del av, studentenes dybdelæring (NOU, 20I4:7, kap. 3).

Halvparten av våre studenter svarte at tolkning av data var vanskelig (tabell 3). Dette kan ha sammenheng med at dataene var kvantitative. I kvantitativ forskning inngår tall og statistikk som må fortolkes, da disse ikke er selvforklarende. Det er liten grunn til å tro at studentene ikke forsto dataene i en barnehagekontekst, da alle studentene hadde erfaring fra praksisfeltet. En mer plausibel forklaring er at flere studenter hadde dårlig numerical literacy, som handler om en persons evne til å bruke og forstå matematikk. Andre studier viser at lærere kan være skeptiske til å involvere studenter i sin forskning fordi studenter ikke har relevant kunnskap og erfaring med forskningslignende aktiviteter (Brew, 2006; Zamorski, 20IO). Fordi inngangskarakterene til førskolelærerstudiet generelt var lavere enn for sammenlignbare profesjonsutdanninger (NOKUT, 20Io), kunne vi i forkant av forskningsprosjektet undervist studentene i matematikk (det elementære prinsippet) for å tilføre studentene den kunnskapen de manglet (det fundamentale prinsippet). Et annet alternativ hadde vært å endre forskningsopplegget, slik at det var mer tilpasset studentenes kompetanse.

Studentene fikk veiledning gjennom hele året, og de bestemte selv hvilket fokus veiledningen skulle ha. Dette tilsvarer research-tutored i Healeys (2005) modell for forskningsbasert utdanning (figur I), som bl.a. har fokus på faglige diskusjoner. Vygotsky (1978) bruker begrepet proksimal utviklingssone for å beskrive kunnskap studentene ikke kan lære på egen hånd men må ha hjelp fra en person med høyere kompetanse. Den tette kontakten vi hadde med enkeltstudenter og mindre grupper, mener vi kan ha bidratt til en mer nyansert forståelse og innsikt i forskningsarbeid generelt, men også til observasjon som metode for innsamling av data spesielt.

\section{Forskningsarbeidets relevans for arbeidet $i$ barnehagen}

Barnehagelærerutdanningen skal være forskningsbasert og profesjonsrettet, og utdanningsinstitusjonene bør etablere samarbeid med praksisfeltet (Kunnskapsdepartementet, 2012). Hele 94\% 
av våre studenter rapporterte at de gjennom forskningsarbeidet hadde fått erfaring og tilegnet seg kunnskap med stor overføringsverdi til arbeidet i barnehagen (tabell 4). Disse resultatene må sees i lys av at alle studentene hadde relevant arbeidserfaring, og at alle arbeidet deltid $\mathrm{i}$ barnehage eller skole ved siden av studiene. Andre studier viser at lærere kan oppleve at det er utfordrende å involvere studenter i forskningslignende aktiviteter på en måte som de opplever som yrkesrelevant og utbytterikt (Kyvik \& Vågan, 20I4).

Vi tror den viktigste årsaken til at vi lyktes med å etablere et praksisrelevant forskningsprosjekt, er at forskningsspørsmålet var knyttet til barns lek i barnehagen. Dette er et av barnehagens kjerneområder. En annen forklaring kan være at studentene lærte om ulike sider ved observasjon, som ofte benyttes i barnehagen for å følge barns utvikling. Slik vi forstår Klafkis dannelsesteorier (20I4), kan vårt opplegg være et eksempel på eksemplarisk læring, der grunntanken er at studenter får "en fundamental forståelse af det elementære i det faglige indhold" (Graf, 2004, s. 72). Et kriterium for eksemplarisk læring er at studentene lærer gjennom å gjøre noe konkret som fører til endring på ulike nivå, og ikke bare leser om det i pensum. Studentene ga eksempler på at forskningen de deltok $\mathrm{i}$ hadde bidratt til videreutvikling og fornying $\mathrm{i}$ egne barnehager. Vår forskning viste for eksempel at barna var svært lite fysisk aktive på barnehagens utelekeplass. Flere barnehager tok initiativ til endring av praksis gjennom å iverksette konkrete tiltak for å tilrettelegge for mer kroppslig lek på barnehagens uteområde. Det elementære og fundamentale prinsippet viser til den doble betydningen av kategorienes subjektivitet og objektivitet. I det eksemplariske blir innholdet, eller det elementære, eksemplifisert gjennom konkrete situasjoner og hendelser. Både observasjon og kroppslig lek er kategorier som studentene var kjent med fra arbeidet $\mathrm{i}$ barnehagen. Disse to kategoriene representerer det elementære kriteriet, mens det fundamentale kriteriet kan være hvordan observasjon av kroppslig lek viser seg å være et nyttig verktøy, både i forskningssammenheng og i det daglige arbeidet i barnehagen (Klafki, 20I4).

Det er interessant at flere studenter iverksetter egne nye praksiser i barnehagen underveis i undervisningsforløpet og på bakgrunn av vårt felles forskningsprosjekt. Dette kan sees i lys av læringsaktiviteten research-based i Healeys modell for forskningsbasert utdanning (2005), hvor både innhold og pensumlitteratur i studiet er tett knyttet opp til det temaet forskningen handlet om. Denne tette koplingen gjør det kanskje lettere å se direkte sammenheng til egen barnehage. Dette utsagnet fra en student kan vise noe av dette: Jeg synes det har vart motiverende å forske og se betydningen av noe og sà ta det med seg videre til arbeidsplassen.

At mange studenter ikke hadde tilegnet seg ferdigheter innen kvantitativ forskning (tabell 3 ), og likevel mente at forskningsarbeidet var relevant for arbeidet i barnehagen (tabell 4), kan forstås på ulike måter. Det kan være at studentene var mer opptatt av resultatene enn av forskningsmetoden, eller at de mente at det ikke var viktig å ha kunnskap om kvantitativ metode når de skal arbeide med forsknings- og utviklingsarbeid i barnehagen. Som tidligere beskrevet kan dette også være et uttrykk for økt innsikt i forskningens kompleksitet.

\section{OPPSUMMERING}

I denne artikkelen har vi presentert deskriptive data fra en spørreundersøkelse der studenter har evaluert et opplegg for forskningsbasert undervisning i faget fysisk fostring. Studentene var deltidsstudenter på førskolelærerutdanningen ved HiOA. Studien viser at det er mulig å gjennomføre studentaktiv forskning med bachelorstudenter selv om studentene var førsteårsstudenter og studentantallet var stort. De fleste studentene opplevde en klar sammenheng mellom 
undervisning og forskning de deltok i sammen med lærerne. Forklaringene kan være måten læringsaktivitetene ble koplet sammen, og/eller at studentene samlet inn data som de senere benyttet i sin skriftlige hjemmeeksamen.

Studentene benyttet kvantitative metoder i forskningen de deltok i sammen med lærerne, noe det er mindre tradisjon for i barnehagefeltet. Flest studenter oppga at de lærte mest om observasjon som metode, og mange lærte å lese forskningsresultater med et kritisk blikk. Selv om begrepet dannelse er uavklart, argumenterer vi for at kombinasjonen av studentsentrerte- og lærersentrerte læringsformer kan ha bidratt til studentenes dannelse, og at vårt opplegg kan ha fellestrekk med prinsippet om eksemplarisk læring (Klafki, 2OI4). En mindre andel av studentene oppga at de hadde tilegnet seg forskningsrelaterte ferdigheter, som det å analysere og tolke kvantitative data. Noe av forklaringen kan være at studentene hadde svak tallforståelse når prosjektet ble igangsatt, samtidig som det kan være et eksempel på dybdelæring.

Vårt forskningsprosjekt for forskningsbasert undervisning viser at første års bachelorstudenter kan ha læringsutbytte av å delta i forskning som er relevant for deres yrkesutøvelse. De fleste studentene mente at forskningsprosjektet var relevant for deres profesjonsutøvelse. Vi tror dette i hovedsak skyldes at forskningsarbeidet var knyttet til lek i barnehagen, som er selve grunnstammen i barnehagens aktiviteter. Kvalitet i profesjonsutdanninger handler om relevant kunnskap og kompetanse for yrkesutøvelsen, og om hvordan de ulike læringsaktivitetene og undervisningsformene støtter opp om studentenes læring.

\section{OM FORFATTERNE}

Heid Osnes er førstelektor ved OsloMet - storbyuniversitetet og underviser og forsker innen kunnskapsområdet Kropp, bevegelse, mat og helse på barnehagelærerutdanningen. Hun har, sammen med andre, skrevet to bøker og flere bokkapitler om lek, kropp og bevegelse. Gjennom mange år har hun utviklet ulike undervisningsformer og tverrfaglige prosjekter for å få studentene aktive i egen læringsprosess.

Hilde Nancy Skaug er universitetslektor ved OsloMet - storbyuniversitetet. Hun underviser i fysisk fostring, og hennes forskningsfelt er fysisk aktivitet i barnehagen. Hun har drevet en stor friluftsbarnehage i Oslo i 19 år og er medforfatter av boken Kropp, bevegelse og helse i Barnehagen (Osnes, Skaug \& Kaarby, 20I7). Deler av boken er utgitt i Sverige med tittelen Kropp, rörelse och hälsa.

\section{REFERANSER}

Boyer Commission (1998). Reinventing undergraduate education: A blueprint for Americas universities. NY:

The Carnegie Foundation for the Advancement of Teaching.

Brew, A. (2006). Research and teaching: Beyond the divide. London: Palgrave Macmillan.

Damşa, Crina, D., De Lange, Thomas, D., Elken, Mari, E., Esterhazy, Rachelle, E., Fossland, Trine, F., Frølich,

Nicoline, F., ... Aamodt, Per Olaf, A. (2015). Quality in Norwegian Higher Education: A review of research on aspects affecting student learning. (NIFU-Rapport, 2015: 24). Hentet fra https://www.nifu.no/ publications/1288405/

Dannelsesutvalget (2009). Kunnskap og dannelse foran et nytt ärhundre. Innstilling fra dannelsesutvalget for bøyere utdanning. Hentet fra https://www.uib.no/filearchive/innstilling-dannelsesutvalget.pdf

Foros, P. B. \& Vetlesen, A. J. (2012). Angsten for oppdragelse: et samfunnsetisk perspektiv på dannelse. Oslo: Universitetsforlaget.

Graf, S. T. (2004). Fylde og Form. Wolfgang Klafki i teori og praksis (1. utg.). Århus: Klim. 
Healey, M. (2005). Linking Research and Teaching: Exploring Disciplinary Spaces and the Role of Inquirybased Learning. I R. Barnett (Red.), Reshaping the university: new relationships between Research, Scholarship and Teaching (s. 67-78). Maidenhead: Open University Press.

Henard, F. and Roseveare, D. (2012) Fostering Quality Teaching in Higher Education: Policies and Practices. OECD Publishing. Hentet frahttps://www.oecd.org/edu/imhe/QT\%20policies\%20and\%20practices. pdf

Hjardemaal, F. R. \& Jordell, K. Ø. (2011). Danning og profesjonsutdanning. Uniped, 34(3), 5-19. Hentet fra https://www.idunn.no/uniped/2011/03/danning_og_profesjonsutdanning

Jenkins, A., Breen, R. \& Lindsay, R. (with Brew, A.). (2003). Reshaping Teaching in Higher Education: Linking Teaching with Research. London: Routledge/SEDA.

Jenkins, A. \& Healey, M. (2010). Undergraduate Research and International Initiatives to Link Teaching and Research. Council on Undergraduate Research, 30(3), 36-42. Hentet fra https://www.cur.org/assets/1/23/303-36-42.pdf

Justice, C., Rice, J., Warry, W., Inglis, S., Miller, S. \& Sammon, S. (2007). Inquiry in Higher Education: Reflections and Directions on Course Design and Teaching Methods. Innovative Higher Education, 31(4), 201-214. https://doi.org/10.1007/s10755-006-9021-9

Klafki, W. (2014). Dannelsesteori og didaktikk - nye studier (3. utg.). Århus: Klim.

Kirke-, utdannings- og forskningsdepartementet. (2001). Gjor din plikt - krev din rett : Kvalitetsreform av høyere utdanning: Tilråding (Meld. St. 27 2000-2001). Hentet fra https://www.regjeringen.no/no/ dokumenter/stmeld-nr-27-2000-2001-/id194247/sec1

Kunnskapsdepartementet (2012). Nasjonal forskrift om rammeplan for barnehagelarerutdanning. Hentet fra https://www.regjeringen.no/no/dokumenter/nasjonal-forskrift-om-rammeplan-for-barn/id684087/

Kunnskapsdepartementet (2013). Lange linjer - kunnskap gir muligheter. (Meld. St. 18 2012-2013). Hentet fra https://www.regjeringen.no/no/dokumenter/meld-st-18-20122013/id716040/sec1

Kunnskapsdepartementet (2016). Tilstandsrapport for høyere utdanning 2016. Hentet fra https://www.regjeringen.no/no/dokumenter/tilstandsrapport-for-hoyere-utdanning-2016/id2498657/

Kunnskapsdepartementet (2017a). Rammeplan for barnehagens innhold og oppgaver. Hentet fra https:// www.udir.no/globalassets/filer/barnehage/rammeplan/rammeplan-for-barnehagen-bokmal2017.pdf

Kulturdepartementet (2017b). Kultur for kvalitet i høyere utdanning. (Meld. St. 16 2016-2017). Hentet fra https://www.regjeringen.no/no/dokumenter/meld.-st.-16-20162017/id2536007/

Kyvik, S. \& Vågan, A. (2014). Forskningsbasert utdanning? Oslo: Abstrakt Forlag AS.

Nnadozie, E., Ishiyama, J. \& Chon, J. (2001). Undergraduate research internships and graduate school success. Journal of College Student Development, 42(2), 145-156. Hentet fra https://search-proquest-com.ezproxy.hioa.no/docview/195176102 ?accountid=26439\&rfr_id=info\%3Axri\%2Fsid\%3Aprimo

NOKUT (2010). Evaluering av forskolelarerutdanningen. Del 1. (NOKUT, Hovedrapport 2010). Hentet fra https://www.nokut.no/contentassets/40568ec86aab411ba43c5a880ae339b5/hovedrapport_ flueva.pdf

NOU 2014:7 (2014). Elevenes laring i fremtidens skole. Elevenes laring i fremtidens skole - Et kunnskapsgrunnlag. Hentet fra https://www.regjeringen.no/no/dokumenter/NOU-2014-7/id766593/

Osnes, H. \& Skaug, H. N. (2015a). Kroppslig lek, fysisk miljø og helse i barnehagen. Første Steg, (2), 18-21.

Osnes, H. \& Skaug H. N. (2015b). Kroppslig lek, voksenkontakt og sosialt lekemiljø i barnehagen. Første Steg, (3), 50-54.

Osnes, H. Skaug, H. N. \& Kaarby, K. M. E.(2017). Kropp, bevegelse og helse i barnehagen (2. utg.). Oslo: Universitetsforlaget.

Pascarella, E. T. \& Terenzini, P. T. (2005). How college affect students: A third decade of research (2nd ed.). San Francisco, CA: Jossey-Bass.

Spronken-Smith, R. \& Walker, R. (2010). Can inquiry-based learning strengthen the links between teaching and disciplinary practice? Studies in Higher Education, 35(6), 723-40. 
Universitets- og høyskoleloven (2005). Lov om universiteter og høyskoler (LOV-2005-04-01-15). Hentet fra https://lovdata.no/dokument/NL/lov/2005-04-01-15?q=Universitet\%20og\%20høyskoleloven

Universitets- og høgskolerådet (2010). Utdanning + FoU = Sant. (Rapport fra arbeidsgruppe nedsatt av Universitets- og høgskolerådet, Juli 2010). Hentet fra https://www.uhr.no/documents/utdanningogfou_ferdigrapport_260810.pdf

Vygotsky, L. S. (1978). Mind in society: The development of higher psychological processes. Cambridge, MA: Harvard University Press

Vågan, A. \& Havnes, A. (2013). Forskningsbasert barnehagelærerutdanning? Norsk pedagogisk tidsskrift, 97(04-05), 292-303.

Zamorski, B. (2010). Research - led Teaching and Learning in Higher Education: A case. Teaching in Higher Education, 7(4), 411-427. https://doi.org/10.1080/135625102760553919 